\title{
Follicular and luteal expression of insulin-like growth factors I and II and the type 1 IGF receptor in the bovine ovary
}

\author{
C. M. Perks, A. R. Peters and D. C. Wathes* \\ Reproduction and Development Group, The Royal Veterinary College, Boltons Park, Hawkshead Road, Potters Bar, \\ Hertfordshire EN6 1NB, UK
}

\begin{abstract}
The localization of mRNAs for insulin-like growth factors I (IGF-I) and II (IGF-II) and the type 1 IGF receptor (IGF-1R) in bovine follicles and corpora lutea was determined using in situ hybridization on sectioned ovaries collected from nonpregnant, cyclic Holstein cows in either the follicular $(n=3)$ or luteal $(n=5)$ phases of the cycle. Concentrations were measured as absorbance units of individual regions or follicles from autoradiographs. There was intense follicular expression of mRNAs encoding IGF-II and IGF-1R. For mRNA encoding IGF-II, expression was significantly higher in smaller follicles $(<5 \mathrm{~mm}$ diameter, $P<0.01)$ and, in this size range, expression was significantly greater in healthy compared with atretic follicles $(P<0.01)$. For mRNA encoding IGF-1R, there was no effect of size but concentrations were again significantly greater in healthy compared with atretic follicles of $<5 \mathrm{~mm}$. In medium $(5-10 \mathrm{~mm})$ and large $(>10 \mathrm{~mm})$ follicles, there was no effect of health for expression of either IGF-II or IGF-1R. mRNA encoding IGF-II was found exclusively in the theca, whereas mRNA encoding IGF-1R was confined to the granulosa layer. IGF-I expression was not detectable in $83 \%$ of the 53 follicles examined. In the remaining $17 \%$ of follicles, expression was very low and was unrelated to size or state of atresia. mRNAs encoding IGF-I, -II and IGF-1R were all present in the corpus luteum, whereas only those for IGF-II and IGF-1R were found in ovarian stroma. These data indicate that the insulinlike growth factors play a significant role in follicular and luteal development in the bovine ovary. Locally produced IGF-II is probably an important regulator of follicular growth, whereas most of the IGF-I present in follicular fluid is likely to be derived from the circulation.
\end{abstract}

\section{Introduction}

The insulin-like growth factors I and II (IGF-I and IGF-II) are single chain polypeptides structurally related to insulin (Froesch et al., 1985). The IGFs mediate their biological actions via a specific cell surface receptor, the type 1 IGF receptor (IGF-1R). The type 2 IGF receptor (IGF-2R) is thought to act as a clearance molecule (Baker et al., 1993; Korner et al., 1995). The actions of the IGFs are modulated by their association with binding proteins, six of which (IGFBP-1-IGFBP-6) have been identified to date (Shimasaki and Ling, 1991; Jones and Clemmons, 1995).

The IGFs exert many actions within the ovary, affecting proliferation, aromatase activity and progesterone biosynthesis in cultures of bovine (Savion et al., 1981; Gong et al., 1993; Spicer et al., 1993), ovine (Monniaux and Pisselet, 1992), human and pig (Kamada et al., 1992) and murine (Adashi et al., 1985) granulosa cells. This effect is increased in synergy with FSH. In luteal cell cultures, both IGF-I and IGF-

*Correspondence.

Revised manuscript received 8 January 1999.
II stimulated progesterone production (McArdle and Holtorf, 1989; Sauerwein et al., 1992). In general, the two peptides have similar effects and both are thought to mediate their biological actions through the type 1 IGF receptor. However, their relative potencies in a particular tissue may be influenced by different affinities for some of the IGF binding proteins also present (Jones and Clemmons, 1995).

Localization of mRNAs encoding for the IGFs in the ovary exhibits marked species specificity. IGF-I expression has been demonstrated in murine (Oliver et al., 1989) and pig (Hatey et al., 1992) granulosa cells and in extracts of whole human ovary (Hernandez et al., 1992), as well as in bovine (Einspanier et al., 1990) and ovine (Perks et al., 1995) corpora lutea. mRNA encoding IGF-II has been detected in ovine thecal cells, corpora lutea and stroma (Perks et al., 1995) in addition to human granulosa cells and extracts of whole human ovary (Hernandez et al., 1992; Zhou and Bondy, 1993).

Despite the many indications that the IGFs are important regulators of follicular and luteal function, it remains uncertain whether there is significant local production within the bovine ovary. The aim of the present study was to 
determine the cellular localization of mRNAs encoding IGF-I, -II and the type 1 IGF receptor in the bovine ovary using in situ hybridization histochemistry and to relate this to follicle size and health.

\section{Materials and Methods}

\section{Animals}

Ovaries were collected at surgery from eight mature, nonpregnant Holstein cows. Bilateral ovariectomy was carried out via a left flank incision using aseptic precautions with the cow restrained in stocks in a standing position. Sedation was induced with $10 \mathrm{mg}$ xylazine i.v. $(0.5 \mathrm{ml}$ Rompun $2 \%(\mathrm{w} / \mathrm{v})$ solution; National Veterinary Supplies, Sandwich). Paravertebral anaesthesia was achieved by infusion of $400 \mathrm{mg}$ lignocaine $(20 \mathrm{ml}$ Locaine $2 \%(\mathrm{w} / \mathrm{v})$, National Veterinary Supplies) just caudal to the first, second and third left lumbar transverse processes. A vertical incision of approximately $20 \mathrm{~cm}$ was made in the skin of the left sub lumbar fossa. The abdominal muscles and peritoneum were incised in turn and the reproductive tract was located by inserting an arm through the incision. An ecraseur was applied to the ovarian pedicle and a chromic catgut ligature was tied tightly around the pedicle immediately behind the ecraseur. The ecraseur was then gradually tightened until the ovary was severed from the pedicle. The abdominal wounds were closed with chromic catgut sutures and the cow was placed in an individual loose box for recovery.

For four cows (batch 1) the exact stage of the ovarian cycle was not known, although they were all judged to be in the luteal phase on the basis of the presence of large corpora lutea. In these cows, both ovaries were removed. The remaining four animals (batch 2) were monitored by collection of blood samples by jugular venepuncture three times a week for measurement of plasma progesterone concentrations for at least one complete ovarian cycle before ovary collection. A portable ultrasound machine (model SSD-500; Aloka Co. Ltd, Tokyo) was used to scan the ovaries. This scanning was performed twice a week during the luteal phase of the cycle but the frequency was increased to once a day as the animals reached the follicular phase. A single ovary containing a large dominant follicle was collected from these cows when the follicular diameter exceeded $15 \mathrm{~mm}$. In three cows, the follicle was judged to be preovulatory whereas, in the fourth cow, the follicle was obtained during the first follicular wave on day 6 of the cycle.

In batch 1 cows, the ovaries were carefully cut into quarters on removal avoiding follicular damage, frozen immediately on dry ice and stored at $-80^{\circ} \mathrm{C}$. In batch 2 cows, the ovary was frozen whole.

\section{Oligonucleotide probes}

All probes were single-stranded 45 base oligonucleotides. The ovine IGF-I probe corresponded to nucleotides 5000 5045 of the ovine IGF-I gene (Dickson et al., 1991) in a region showing $98 \%$ homology for the bovine gene. The antisense sequence was: 5'-GAG-CAA-GCA-CAG-GGC-CAG-ATAGAA-GAG-ATG-CGA-GGA-TGT-GAC-3'.

The ovine IGF-II probe was taken from the first coding exon (exon 4) of the ovine IGF-II gene (Li et al., 1993) in a region showing $100 \%$ homology with the bovine gene. The antisense sequence was: $5^{\prime}$-AAC-TGG-AGG-GTG-TCACCA-GCT-CCC-CGC-CGC-ACA-GAG-TCT-CGC-TGG-3'

The type 1 IGF receptor probe sequence corresponded to nucleotides 338-383 of the human IGF-1 receptor gene. The corresponding bovine sequence is not known but the region chosen shows high homology between species (Ullrich et al., 1986). The antisense sequence was: 5'-CAG-GGC-GTAGTT-GTA-GAA-GAG-TTT-CCA-GCC-GCG-GAT-GAC-CGTGAG-3'.

All probes were lyophilized and reconstituted in diethylpyrocarbonate (DEPC)-treated water to a final concentration of $5 \mathrm{ng} \mathrm{hl}^{-1}$. Sense probes corresponding to each of the antisense probes were also included as a control. These were identical in sequence to the respective mRNA targets and, therefore, any signal detected with these probes was categorized as nonspecific.

\section{In situ hybridization}

Chemicals were purchased from Sigma Chemical Company, Poole or Merck, Poole unless otherwise stated. Frozen sections $(18 \mu \mathrm{m})$ of bovine ovaries were thawmounted onto poly-L-lysine-coated $\left(0.1 \mathrm{mg} \mathrm{ml}^{-1}\right)$ glass slides and fixed in $4 \%(\mathrm{w} / \mathrm{v})$ paraformaldehyde in $0.01 \mathrm{~mol} \mathrm{PBS} \mathrm{l}^{-1}$, pH 7.4 for $5 \mathrm{~min}$ as described by Perks et al. (1995). Slides were then immersed in two washes of PBS, pH $7.4(1 \mathrm{~min}$ each) and dehydrated in $70 \%(5 \mathrm{~min})$ and $95 \%(1 \mathrm{~min})$ ethanol before storing at $4{ }^{\circ} \mathrm{C}$ under $95 \%$ ethanol in sterile, plastic boxes. For batch 1 cows, two sections were taken from each ovarian quarter. For batch 2 cows, the ovary containing the large follicle was serially sectioned. Two regions were chosen for in situ hybridization, one passing through the largest diameter follicle, the other at another region containing a different selection of follicles. Four slides of each region, each containing two sections, were used for each probe; two were treated with the antisense probe and two with the sense probe as controls. An adjacent section was stained with haematoxylin and eosin to aid follicular classification.

The oligonucleotide probes were labelled and the sections incubated as described by Stevenson et al. (1994). The oligonucleotide $(5 \mathrm{ng})$ was end-labelled with ${ }^{35}$ S-labelled ATP (dATP; Amersham International, Aylesbury) using deoxynucleotidyl transferase (Pharmacia Biotech, St Albans) at $34^{\circ} \mathrm{C}$ for $1 \mathrm{~h}$. The labelled probe was diluted to a final concentration of 1100000 c.p.m. ml ${ }^{-1}$ hybridization buffer $(50 \%(\mathrm{v} / \mathrm{v})$ deionised formamide, $4 \times$ sodium saline citrate (SSC), $25 \mathrm{mmol}$ sodium phosphate $\mathrm{1}^{-1}, 1 \mathrm{mmol}$ sodium pyrophosphate $\mathrm{l}^{-1}, 5 \times$ Denhardt's solution, $0.2 \mathrm{mg}$ denatured salmon sperm DNA ml-1, $120 \mu \mathrm{g}$ sodium heparin $\mathrm{ml}^{-1}, 100 \mu \mathrm{g}$ polyadenylic acid ml-1 and $100 \mathrm{mg}^{-1}$ dextran sulphate $\mathrm{ml}^{-1}$ ) and added to each section. After incubation overnight in an 
humidified box at $42.5^{\circ} \mathrm{C}$, the slides were washed in a solution of $1 \times \mathrm{SSC}$ containing $0.5 \% \quad \beta$-mercaptoethanol at room temperature for $30 \mathrm{~min}$, then at $55^{\circ} \mathrm{C}$ for $1 \mathrm{~h}$, rinsed in solutions of $1 \times$ SSC, $0.1 \times$ SSC, $70 \%$ and $95 \%$ ethanol $(1 \mathrm{~min}$ each), allowed to dry and exposed to X-ray film at room temperature for 18 days. Subsequently, the slides were coated with a film of photographic emulsion, LM1, according to manufacturer's instructions (Amersham International), stored for 28 days at $4^{\circ} \mathrm{C}$ in the dark, developed and counterstained with haematoxylin and eosin. Cross-section samples of uteri from oestrous ewes, previously shown positive for IGF-I, IGF-II and the type 1 IGF receptor (Stevenson t al., 1994), were included in each experiment as positive control tissues.

\section{Follicular characterization}

The follicles were characterized according to their size, very small $(<2.5 \mathrm{~mm})$, small $(2.5-5.0 \mathrm{~mm})$, medium $(5-10 \mathrm{~mm})$ or large $(>10 \mathrm{~mm})$. The stage of atresia was also assessed by morphological criteria (Ireland and Roche, 1983a,b; Savio et al., 1988). Follicles classified as non-atretic had healthy looking granulosa cells with few pyknotic nuclei and the theca interna was smaller in thickness than the granulosa layer. Atretic follicles had a sparse granulosa with abundant pyknotic nuclei and the thecal layer was generally thicker than the granulosa layer.

\section{Absorbance quantification}

The method of quantification has been described by Perks et al. (1995). Within each batch of ovaries, all samples treated with the same probe were processed against the same film. The relative expression of mRNAs in different ovarian compartments encoding IGF-I, IGF-II and the type 1 IGF receptor was quantified from the autoradiographs using a Seescan Image Analysis package (Seescan Imaging plc, Cambridge), which calculated the average absorbance over the selected area of the film based on a linear grey scale of 0-2.1. An autoradiograph was placed under the lens of the image analyser, the background of the blank film was subtracted from the image, and specific areas were outlined. Accurate absorbance readings of the walls of individual follicles could be obtained using this method, and antisense (AS) and sense (S) readings from the same follicle could be compared. The absorbance values of the $S$ were subtracted from the AS values to give a final average absorbance value for specific hybridization for each region or follicle. An absorbance value of 0.01 was taken as the limit of detection for statistical purposes.

\section{Progesterone ELISA}

Progesterone concentrations were monitored using an enzyme immunoassay kit (Ridgeway Science, Alvington) to detect the timing of the preovulatory fall with a detection range of $0.5-20.0 \mathrm{ng} \mathrm{ml}^{-1}$.

\section{Statistical analysis}

The absorbance data from the follicles were analysed by two-way ANOVA for each probe with health (healthy or atretic) and size (very small $(<2.5 \mathrm{~mm})$, small $(2.5-5.0 \mathrm{~mm})$, medium $(5-10 \mathrm{~mm})$ or large $(>10 \mathrm{~mm}))$ as the factors. Subsequent comparisons among groups were made using Fisher's pairwise comparisons.

\section{Results}

Measurement of plasma progesterone concentrations confirmed that all three of the ovaries collected from the cows identified as preovulatory showed a decrease in progesterone from luteal phase concentrations of $>10 \mathrm{ng} \mathrm{ml}^{-1}$ to follicular phase concentrations of $<2 \mathrm{ng} \mathrm{ml}^{-1}$ before surgery.

\section{Distribution of mRNA encoding IGF-II}

Analysis of the autoradiographs showed that mRNA encoding IGF-II was located in the follicles, ovarian stroma and corpus luteum (Figs 1 and 2). Analysis of the emulsion autoradiographs revealed that follicular expression was confined to the thecal layer. The absorbance was low in the stroma $(0.05 \pm 0.01, n=18$ readings). In the corpus luteum, the absorbance was higher in the luteal phase cows $(0.12$ and $0.25, n=2)$ than in the follicular phase cows $(0.06$ and 0.06 , $n=2)$. IGF-II was expressed intensely in very small and small follicles. Expression decreased in medium and large follicles (Fig. 3). In very small and small follicles, IGF-II expression was significantly reduced in atretic compared with healthy follicles. This difference was no longer present in the medium follicles, in which expression was already lower in the healthy follicles.

\section{Distribution of the type 1 IGF receptor}

Analysis of the autoradiographs demonstrated expression of mRNA encoding type 1 IGF receptor in the stroma, corpus luteum and ovarian follicles (Figs 2 and 4). The emulsion autoradiographs revealed that the expression of type 1 IGF receptor mRNA was located in the granulosa layer of the follicle wall and in the granulosa-derived large luteal cells in the corpus luteum. The absorbance was very low in the stroma (0.02 $\pm 0.007, n=14$ readings) but higher in the corpus luteum $(0.14 \pm 0.02, n=4)$ and corpus albicans from the follicular phase cows $(0.06 \pm 0.006, n=3)$. Expression was intense in healthy follicles of all sizes but was significantly lower in atretic follicles (Fig. 3). The difference between healthy and atretic follicles was again more pronounced in the smaller follicles. 

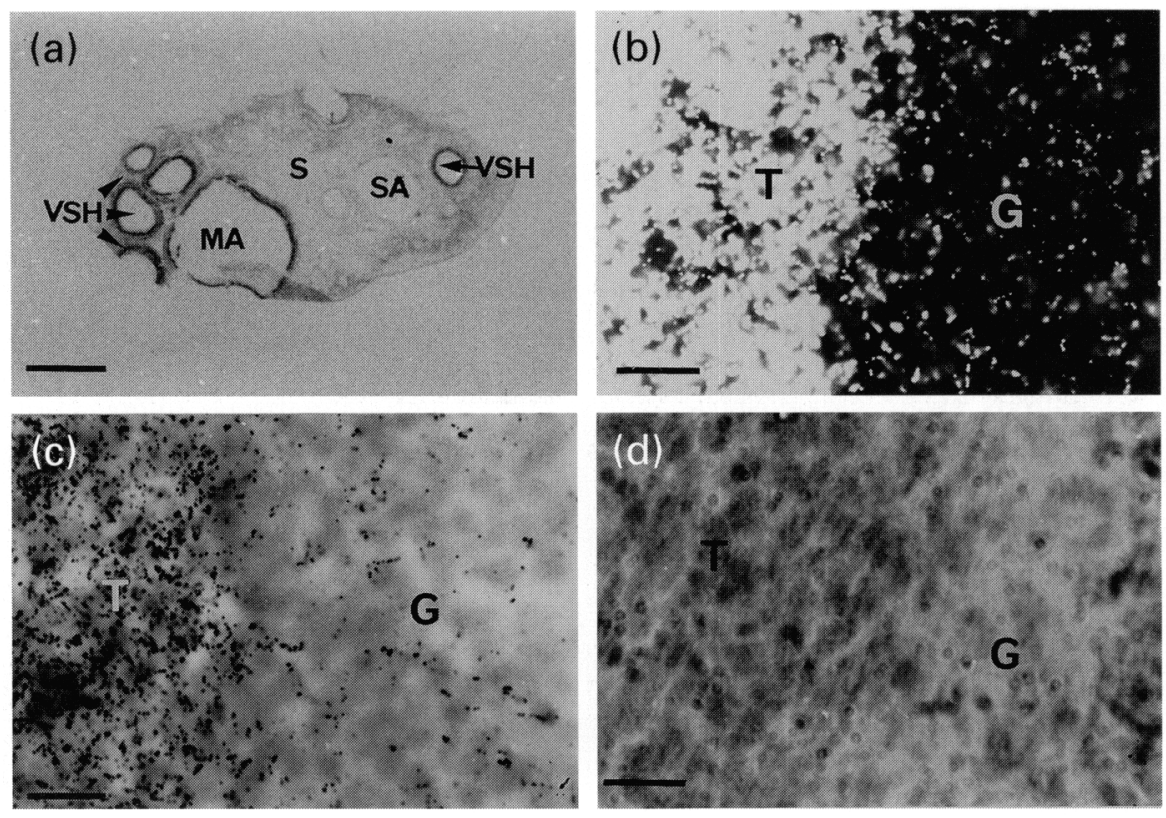

Fig. 1. Expression of mRNA encoding insulin-like growth factor II (IGF-II) in the bovine ovary. (a) Antisense autoradiograph of an ovary collected during the luteal phase of the cycle with ovarian stroma (S), very small, healthy (VSH), small atretic (SA) and medium atretic (MA) follicles. There is strong hybridization to the walls of the very small and medium atretic follicles, with much lower concentrations present in the small atretic follicle and ovarian stroma. (b) Darkfield section of a very small follicle shown in (a) hybridized with the IGF-II antisense probe. (c,d) Sections from the same follicle as in (b) hybridized with the IGF-II mRNA antisense and sense probes, respectively. These demonstrate that the signal is located in the thecal layer $(T)$ of the follicle wall rather than the granulosa layer $(G)$. Scale bars represent (a) $40 \mathrm{~mm}$, (b-d) $10 \mu \mathrm{m}$.

\section{Distribution of IGF-I}

Examination of the autoradiographs revealed barely detectable expression of mRNA encoding IGF-I in the corpus luteum of the luteal phase cows $(0.02 \pm 0.004, n=4)$ but no expression in the follicular phase cows (absorbance $<0.01$, $n=2$ ) or ovarian stroma (absorbance always $<0.01$; Fig. 2). Of 53 follicles examined, IGF-I expression was below the detectable limit in 44 (absorbance $<0.01,83 \%$ ). In the remaining nine follicles, very low expression $(0.05 \pm 0.01$, $n=9$ ) was measured from the autoradiographs, but the increase in grain intensity on the emulsions was not sufficiently distinct to detect whether this was in the granulosa or theca layer. These nine follicles were not of any particular size or state (three very small, healthy follicles; one very small, atretic follicle; one small, healthy follicle; two small, atretic follicles; one medium, healthy follicle; and one large, healthy follicle).

\section{Discussion}

This investigation demonstrates the localization of mRNAs encoding the IGFs and the type 1 IGF receptor in bovine follicles and corpora lutea. Both IGF-I and -II influence ovarian activity. This study revealed that IGF-I expression is extremely low in the bovine ovary. Concentrations were barely detectable in the corpus luteum and were below the detection limit in our system in $83 \%$ of follicles. However, the probe used detected mRNA encoding IGF-I in the bovine uterus (Robinson et al., 1997), confirming that it works in this species. Previous workers have reported IGF-I expression in the bovine corpus luteum (Einspanier et al., 1990; Vanderhaar et al., 1995; Kirby et al., 1996), although Kirby et al. (1996) also found that expression was low in comparison with that in the uterus. IGF-I protein has also been localized to the cow corpus luteum by immunohistochemistry (Amselgruber et al., 1994). Therefore, the case in support of luteal expression is strong.

It is less certain whether there is significant follicular production. Cohick et al. (1996) reported mRNA encoding IGF-I in whole ovaries of prepubertal heifers using an RNase protection assay, and Spicer et al. (1993) measured mRNA encoding IGF-I in granulosa cells from cows treated with a superovulatory regimen by northern blot analysis. In contrast, no IGF-I expression was detected in bovine follicles by Armstrong et al. (1998) using in situ hybridization with homologous RNA probes, and cultured non-luteinized 

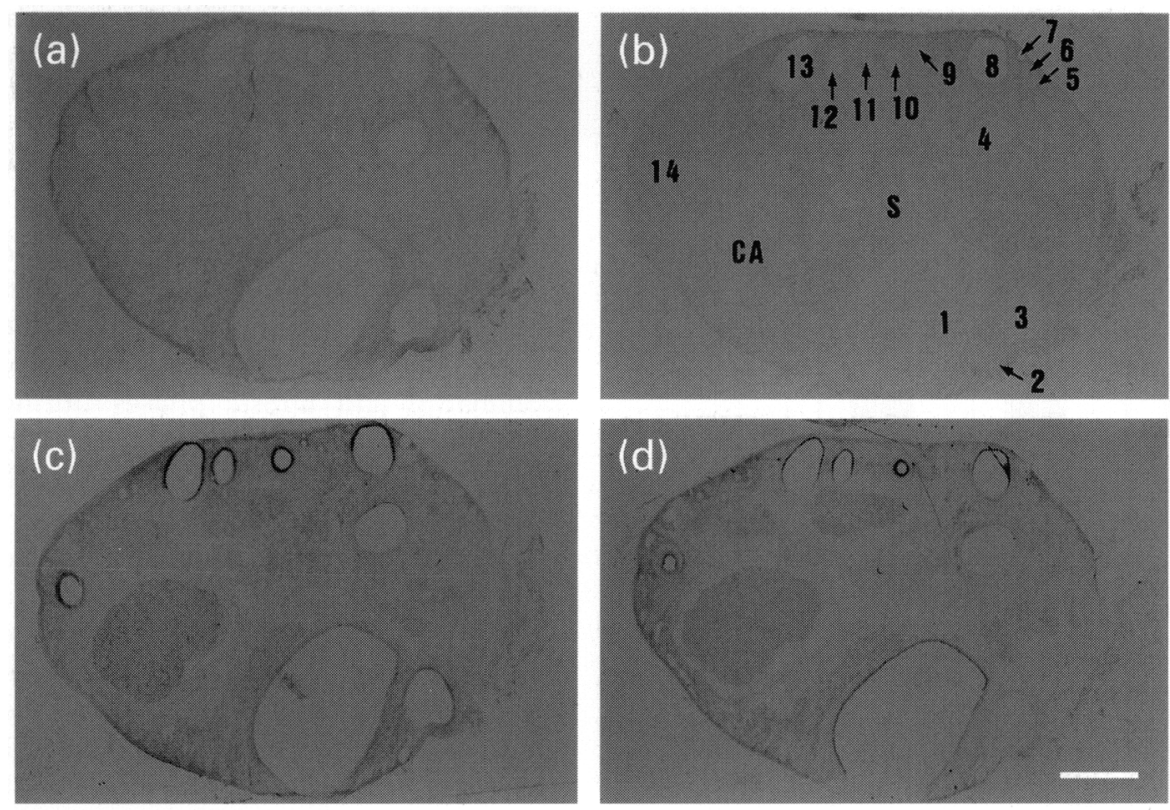

Fig. 2. Sections of a bovine ovary collected in the follicular phase of the cycle and hybridized with (a) insulin-like growth factor I (IGF-I) antisense probe, (b) IGF-I sense probe, (c) IGF-II antisense probe and (d) IGF-I receptor antisense probe. The 14 follicles identified in these sections were classified as follows: very small, healthy; numbers 2, 5, 6,9-12; very small, atretic, numbers 7, 14; small, healthy, numbers 8, 13; small, atretic, numbers 3, 4; large, healthy (preovulatory follicle), number 1 . The regressing corpus luteum of the previous cycle (corpus albicans, CA) and the ovarian stroma (S) are also shown. There is no obvious hybridization of follicles with the IGF-I probe, whereas IGF-II and IGF-I receptor expression is most evident in the very small, healthy and small healthy follicles, with lower concentrations in the CA. Scale bar represents $20 \mathrm{~mm}$.

bovine granulosa cells also failed to produce any detectable IGF-I in vitro (Gutierrez et al., 1997). In situ hybridization in the present study revealed very low expression of mRNA encoding IGF-I in a small minority of follicles and no trend was apparent in relation to the size of follicle or to the state of atresia.

Several authors have compared follicular fluid IGF-I concentrations with those in plasma in cattle and sheep. Follicular fluid and plasma IGF-I concentrations are highly correlated, but values are either similar or lower in the follicular fluid than in the circulation (Stanko et al., 1994; Funston et al., 1996; Leeuwenberger et al., 1996). There is also no effect of growth hormone treatment (Kirby et al., 1996), active immunization against growth hormone-releasing factor (Cohick et al., 1996), the LH surge (Funston et al., 1996), energy balance (Spicer et al., 1991; Vanderhaar et al., 1995), fasting (Spicer et al., 1992), follicular dominance (de la Sota et al., 1996) or size (present paper) on ovarian mRNA encoding IGF-I or peptide measurements in the bovine ovary, although Echternkamp et al. (1990) reported that IGF-I concentrations were higher in the follicular fluid from oestrogen-active follicles than in follicular fluid from oestrogen-inactive follicles. Together, these data suggest: (i) that local production of IGF-I within the bovine follicle is either absent or extremely low and (ii) that ovarian concentrations of IGF-I are not tightly regulated. Therefore, the contribution of circulating IGF-I will exceed that of IGF-I produced by the ovary, making endocrine effects more important than paracrine or autocrine actions. In addition, the reported effects of IGF-I on the ovary are more likely to be controlled by changes in local receptor or binding protein expression than by variations in ovarian IGF-I production. This finding is in agreement with studies in sheep (Perks et al., 1995; Wathes of al., 1995) but is in contrast to studies in other species, including rats (Oliver et al., 1989), pigs (Hatey et al., 1992) and humans (Hernandez et al., 1992), in which follicular production of IGF-I has been demonstrated more clearly.

In contrast, there was intense expression of mRNA encoding IGF-II in the follicular theca layer, particularly in small, healthy follicles. This pattern of distribution is identical to the localization of mRNA encoding IGF-II in sheep (Perks et al., 1995) but is in contrast to the pattern in humans, in which mRNA encoding IGF-II has been found only in the granulosa layer (Hernandez et al., 1992; Zhou and Bondy, 1993). Small ovarian follicles have a greater capacity to proliferate, whereas larger follicles have a greater steroidogenic ability with limited proliferative activity. Both 

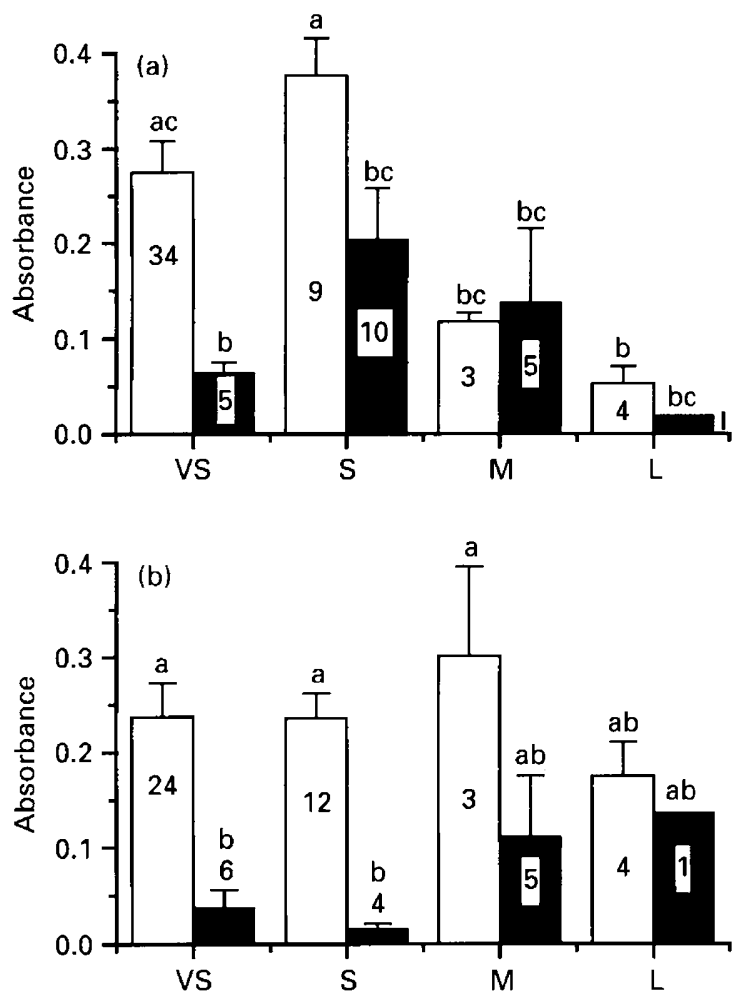

Fig. 3. The effect of health and size on the expression of mRNAs encoding (a) insulin-like growth factor (IGF)-II and (b) IGF-I receptor in bovine follicles. The number of follicles of each size group is given on the histograms: VS, very small $(<2.5 \mathrm{~mm})$; $\mathrm{S}$, small $(2.5-5.0 \mathrm{~mm}) ; \mathrm{M}$, medium $(5-10 \mathrm{~mm})$; L, large (>10 mm). $\square$, Healthy; $\boldsymbol{\square}$, atretic. Values are mean \pm SEM absorbance concentrations, measured from the autoradiographs. For IGF-II, there were highly significant effects of both health and size (ANOVA; $P<0.01)$. For IGF-1 receptor, health $(P<0.001)$, but not size, had significant effects. Bars with different superscripts are significantly different.

of these processes may be stimulated by IGFs (Kamada et al., 1992; Monniaux and Pisselet, 1992; Gong et al., 1993). Therefore, the intense localization of mRNA encoding IGF-II in small, bovine follicles indicates that it plays a role in cell proliferation. This finding is supported by the data on the localization of the type 1 receptor through which IGF-II is thought to exert its biological response (Jones and Clemmons, 1995). The present study demonstrated high expression of type 1 IGF receptor in the granulosa of healthy follicles of all sizes. Similar results have been reported for humans (Bondy and Zhou, 1993) and rats (Zhou et al., 1991). In cows, the concentration of mRNA encoding IGF-1R was reported to increase with increased follicular diameter (Spicer et al., 1994) whereas, in sheep, a decrease in expression with increasing size has been reported (Perks et al., 1995). Neither trend was apparent from the present data. Taken together, these results indicate that thecal IGF-II in cows is probably affecting cell proliferation by acting in a paracrine manner via the type 1 IGF receptor in the granulosa layer of the follicle wall.
The present study demonstrated a marked reduction in IGF-1R expression in atretic follicles, corroborating studies in bovine fetuses and neonatal calves in which atretic follicles were also found to possess significantly lower numbers of IGF-I receptors than healthy ones (Wandji et al., 1992). Furthermore, mRNA encoding IGF-IR disappeared in the granulosa cells of atretic rat follicles (Zhou et al., 1991) in contrast to the granulosa cells of other species, including sheep (Perks et al., 1995) and humans (Balboni et al., 1987), in which the opposite trend was observed. Selection, dominance and atresia phases during waves of bovine follicular development are correlated with subsequent increases and decreases in FSH (Sunderland et al., 1994). Furthermore, treatment of granulosa cells with epidermal growth factor, oestradiol and FSH increases the number of type 1 IGF receptors so that granulosa cells acquire IGF-1 receptors during differentiation (Spicer et al., 1994). As bovine follicles develop, the hormonal environment becomes conducive to increasing IGF-1R expression so that follicles are able to respond maximally to the IGFs. Therefore, the reduction in mRNA encoding IGF-1R observed during atresia may be associated with functional regression due to a reduction in hormonal stimulation of follicle growth.

Other workers have demonstrated that high affinity binding sites for IGF-II are present in the bovine corpus luteum (Sauerwein et al., 1992). Type 2 receptors have also been reported on thecal cells from healthy follicles but on granulosa cells from atretic ones in ewes (Teissier et al., 1994) and on granulosa cells from human dominant follicles (El-Roeity et al., 1993). However, the data of Adashin et al. (1990) imply that IGF-II is more likely to be acting via the type 1 IGF receptor in the ovary and Korner et al. (1995) demonstrated that the type 2 receptor is not involved in cell signalling.

The present data show that mRNAs encoding IGF-1R, IGF-I and -II are all expressed in the bovine corpus luteum. The presence of mRNA encoding IGF-I and IGF-II was undetectable in the cyclic rat corpus luteum (Oliver et al., 1989), although it is present during pregnancy (Parmer et al., 1991). Species-specific differences in ovarian function may explain this disparate localization of IGF-I and -II in the ovary as the murine corpus luteum is short-lived and non-functional (in terms of progesterone biosynthesis) unless mating occurs at oestrus (Short 1972; McDonald 1975). The ruminant corpus luteum secretes large amounts of progesterone during both the cycle and pregnancy, and progesterone production was increased by IGF-I and -II in cultures of bovine luteal tissue (Sauerwein et al., 1992; McArdle and Holtorf, 1989). Therefore, IGF-I may play a paracrine or autocrine role within the ruminant corpus luteum to stimulate progesterone production.

Low concentrations of mRNAs encoding IGF-II and type 1 IGF receptor were also detected in bovine stromal tissue. The cells of the theca are derived from the fibroblast-like stromal cells. There are very indistinct boundaries between the theca interna, theca externa and stroma (Fawcett, 1986) and it is not yet known what triggers the stromal cells to differentiate into the steroid-secreting thecal cells. Expression of IGF-II and IGF-1R within the stromal cells indicates a role for this peptide in cell differentiation. 

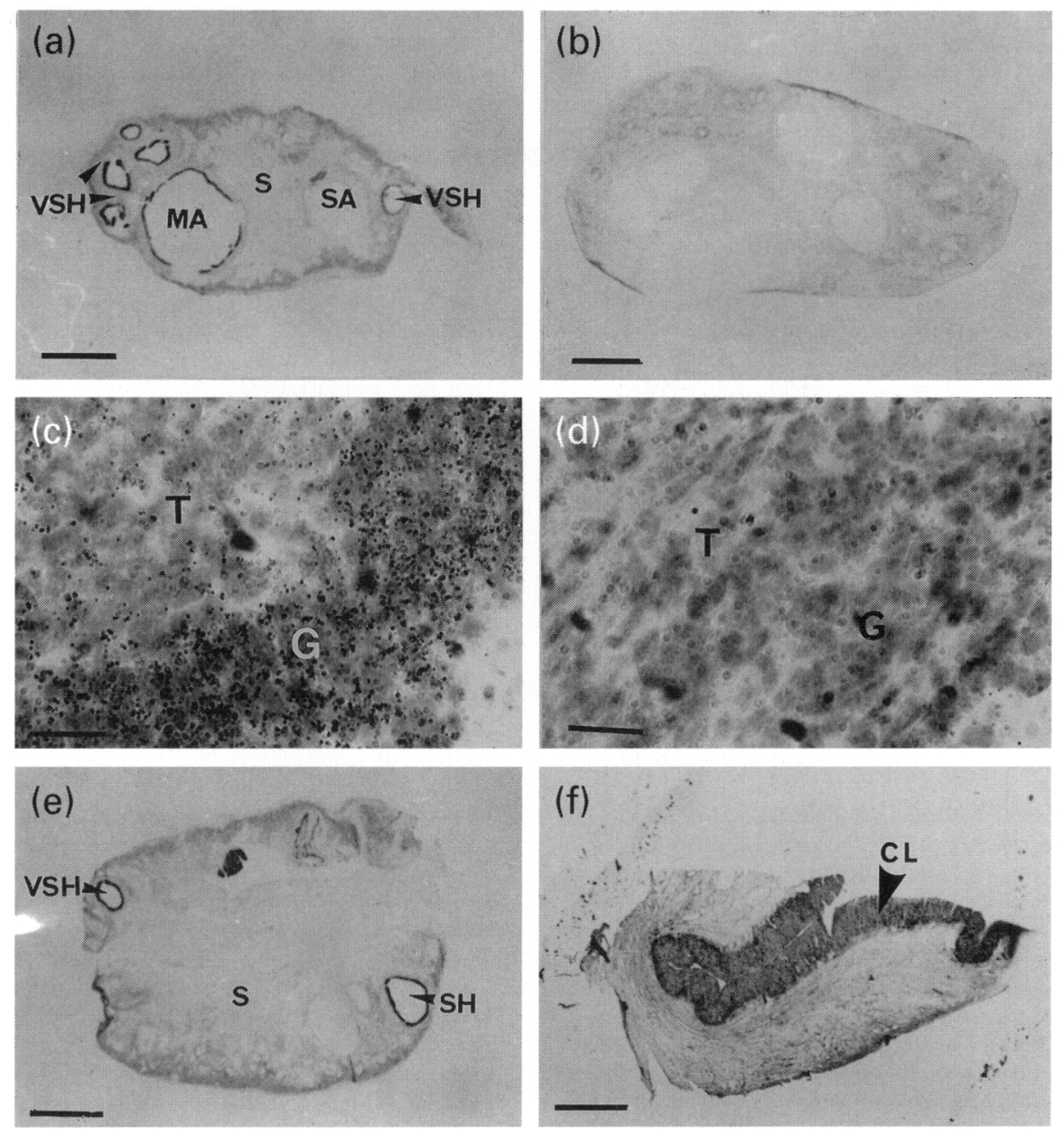

Fig. 4. Expression of mRNA encoding insulin-like growth factor (IGF)-I receptor in the bovine ovary. Antisense (a) and sense (b) autoradiographs of an ovary collected during the luteal phase of the cycle. (a) High expression of IGF-I receptor mRNA in the very small healthy (VSH) and medium atretic (MA) follicles with lower expression in the small atretic (SA) follicle and ovarian stroma (S). Sections from one of the VSH follicles shown in (a) hybridized with the IGFIR antisense (c) and sense (d) probes respectively, demonstrating localization in the granulosa layer $(G)$ of the follicle wall rather than the theca $(T)$. $(e, f)$ Antisense autoradiographs of two more ovaries collected during the luteal phase of the cycle showing intense expression of IGF-I receptor in the small and very small healthy follicles (SH and VSH) and corpus luteum (CL) with lower concentrations in the stromal tissue. Scale bars represent $(a, b, e, f) 40 \mathrm{~mm}$, (c,d) $10 \mu \mathrm{m}$.

In conclusion, clear expression of mRNAs encoding IGF-II and the type 1 receptor has been demonstrated within bovine follicles and corpus luteum. Ovarian expression of IGF-I is much lower and is likely to be relatively unimportant in contrast to IGF-I derived from the circulation.

The authors wish to thank S. Bray and M. Parrott for care of the animals, D. Gunn and B. Wilsmore for the photography, A. Lane for performing the progesterone ELISAs and ovarian scanning and $Z$. Cheng for statistical analysis. The work was supported by the BBSRC.

\section{References}

Adashi EY, Resnick CE, D'Ercole AJ, Svoboda ME and Van Wyk JJ (1985) Insulin-like growth factors as intraovarian regulators of granulosa cells: growth and function Endocrine Reviews $6400-421$

Adashi EY, Resnick CC and Rosenfeld RG (1990) Insulin like growth factor I (IGF-I) and IGF-II hormonal action in cultured rat granulosa cells: mediation via type 1 but not type II IGF receptors Endocrinology 126 216-222

Amselgruber W, Sinowatz F, Schams D and Skottner A (1994) Immunohistochemical aspects of insulin-like growth factors I and II in the bovine corpus luteum Journal of Reproduction and Fertility 101 445-451

Armstrong DG, Gutierrez CG, Woad KJ, Baxter G, Hogg CO and Webb R 
(1998) The anatomy of the bovine ovarian IGF system Journal of Endocrinology 156 (Supplement) 264

Baker J, Lui J-P, Robertson EJ and Efstratiadis A (1993) Role of insulin-like growth factors in embryonic and postnatal growth Cell 75 73-82

Balboni GC, Vannelli GB, Barni T, Orlando C and Serio M (1987) Transferrin and somatomedin $C$ receptors in the human ovarian follicles Fertility and Sterility 48 796-801

Bondy C and Zhou J (1993) Insulin-like growth factor system gene expression in the postpubertal human ovary Annals of the New York Academy of Sciences 687 65-76

Cohick WS, Armstrong JD, Whitacre MD, Lucy MC, Harvey RW and Campbell RM (1996) Ovarian expression of insulin-like growth factor-I (IGF-I), IGF binding proteins and growth hormone (GH) receptor in heifers actively immunized against GH-releasing factor Endocrinology 137 1670-1676

de la Sota RL, Simmen FA, Diaz T and Thatcher WW (1996) Insulin-like growth factor system in bovine first-wave dominant and subordinate follicles Biology of Reproduction 55 803-812

Dickson MC, Saunders JC and Gilmour RS (1991) The ovine insulin-like growth factor-I gene: characterization, expression and identification of a putative promoter Journal of Molecular Endocrinology 6 17-31

Echternkamp SE, Spicer LJ, Gregory KE, Canning SF and Hammond JM (1990) Concentrations of insulin-like growth factor-I in blood and ovarian follicular fluid of cattle selected for twins Biology of Reproduction 43 8-14

Einspanier R, Miyamoto A, Schams D, Müller M and Brem G (1990) Tissue concentration, mRNA expression and stimulation of IGF-I in luteal tissue during the oestrous cycle and pregnancy of cows Journal of Reproduction and Fertility $90439-445$

El-Roeity A, Chen X, Roberts VJ, LeRoith D, Roberts CT and Yen SSC (1993) Expression of insulin-like growth factor-I (IGF-I) and IGF-II and IGF-I, IGFII, and insulin receptor genes and localization of the gene products in the human ovary Journal of Clinical Endocrinology and Metabolism 78 1488-1496

Fawcett DW (1986) Female reproductive system. In A Textbook of Histology 11 th Edn p 857 Ed. D Dreibelbis. WB Saunders Company, Philadelphia, PA

Froesch ER, Schmid C, Schwander J and Zapf J (1985) Actions of insulin-like growth factors Annual Reviews in Physiology $47443-467$

Funston RN, Seidel GE, Klindt J and Roberts AJ (1996) Insulin-like growth factor I and insulin-like growth factor-binding proteins in bovine serum and follicular fluid before and after preovulatory surge of luteinizing hormone Biology of Reproduction 55 1390-1396

Gong JG, McBride D, Bramley TA and Webb R (1993) Effects of bovine somatotrophin, insulin-like growth factor-I and insulin on the proliferation of bovine granulosa cells in vitro. Journal of Endocrinology 139 67-75

Gutierrez GC, Campbell BK, Armstrong DG and Webb R (1997) Insulin-like growth factor-I (IGF-I) production by bovine granulosa cells in vitro and peripheral IGF-I measurement in cattle serum: an evaluation of IGF-binding protein extraction protocols Journal of Endocrinology 153 231-240

Hatey F, Langlois I, Mulsant P, Bonnet A, Benne F and Gasser F (1992) Gonadotropins induce accumulation of insulin-like growth factor I mRNA in pig granulosa cells in vitro. Molecular and Cellular Endocrinology 86 205-211

Hernandez ER, Hurwitz A, Vera A, Pellicer A, Adashi EY, LeRoith D and Roberts CT (1992) Expression of the genes encoding the insulin-like growth factors and their receptors in the human ovary journal of Clinical Endocrinology and Metabolism 74 419-425

Ireland JJ and Roche JF (1983a) Development of nonovulatory antral follicles in heifers: changes in steroids in follicular fluid and receptors for gonadotropins Endocrinology 112 150-156

Ireland JJ and Roche JF (1983b) Growth and differentiation of large antral follicles after spontaneous luteolysis in heifers: changes in concentration of hormones in follicular fluid and specific binding of gonadotropins to follicles Journal of Animal Science 57 157-167

Jones JI and Clemmons DR (1995) Insulin-like growth factors and their binding proteins: biological actions Endocrinology Review 16 3-34

Kamada S, Kubota T, Taguchi M, Ho WR, Sakamoto S and Aso T (1992) Effects of insulin-like growth factor II on proliferation and differentiation of ovarian granulosa cells Hormone Research 37 141-149

Kirby CJ, Thatcher WW, Collier RJ, Simmen FA and Lucy MC (1996) Effects of growth hormone and pregnancy on expression of growth hormone receptor, insulin-like growth factor-I, and insulin-like growth factor binding protein 2 and 3 genes in bovine uterus, ovary and oviduct Biology of Reproduction 55 996-1002

Korner C, Nurnberg B, Uhde $\mathbf{M}$ and Braulke T (1995) Mannose 6phosphate/insulin-like growth factor II receptor fails to interact with G- proteins. Analysis of mutant cytoplasmic receptor domains Journal of Biological Chemistry 270 287-295

Leeuwebberg BR, Hudson NL, Moore LG, Hurst PR and McNatty KP (1996) Peripheral and ovarian IGF-I concentrations during the ovine oestrous cycle Journal of Endocrinology 148 281-289

Li J, Saunders JC, Gilmour RS, Silver M and Fowden AL (1993) Insulin-like growth factor II messenger ribonucleic acid expression in fetal tissues of the sheep during late gestation: effects of cortisol Endocrinology 132 2083-2089

McArdle CA and Holtorf AP (1989) Oxytocin and progesterone release from bovine corpus luteal cells in culture: effects of insulin-like growth factor I, insulin and prostaglandins Endocrinology 124 1278-1286

McDonald LE (1975) The female reproductive system. In Veterinary Endocrinology 2nd Edn pp 247-303. Lee and Feebiger, Philadelphia, PA

Monniaux P and Pisselet C (1992) Control of proliferation and differentiation of ovine granulosa cells by insulin-like growth factor I and folliclestimulating hormone in vitro. Biology of Reproduction 46 109-119

Oliver JE, Aitman TJ, Powell JF, Wilson CA and Clayton RN (1989) Insulinlike growth factor $I$ gene expression in the rat ovary is confined to the granulosa cells of developing follicles Endocrinology 124 2671-2679

Parmer TG, Roberts CT, LeRoith D, Adashi EY, Khan I, Solan N, Nelson S, Zilberstein $\mathbf{M}$ and Gibori G (1991) Expression, action and steroidal regulation of insulin-like growth factor-I (IGF-I) and IGF-I receptor in the rat corpus luteum: their differential role in the two cell populations forming the corpus luteum Endocrinology 129 2924-2932

Perks CM, Denning-Kendall PA, Gilmour RS and Wathes DC (1995) Localization of messenger ribonucleic acids for insulin-like growth factor I (IGF-I), IGF-II and the type I IGF receptor in the ovine ovary throughout the estrous cycle Endocrinology 136 5266-5273

Robinson RS, Mann GE, Lamming GE and Wathes DC (1997) The localization of IGF-I, -II and IGF type I receptor in the bovine uterus on day 16 of pregnancy Journal of Endocrinology 155 Supplement 264

Sauerwein H, Miyamoto A, Gunther J, Meyer HH and Schams D (1992) Binding and action of insulin-like growth factors and insulin in bovine luteal tissue during the oestrous cycle Journal of Reproduction and Fertility 96 103-115

Savio JD, Keenan L, Boland MP and Roche JF (1988) Pattern of growth of dominant follicles during the oestrous cycle of heifers Journal of Reproduction and Fertility $83663-671$

Savion N, Lui GM, Laherty R and Gospodarowicz D (1981) Factors controlling proliferation and progesterone production by bovine granulosa cells in serum-free medium Endocrinology $109409-420$

Shimasaki S and Ling N (1991) Identification and molecular characterization of insulin-like growth factor binding proteins (IGFBP-1,2,3,4,5 and -6) Progress in Growth Factor Research 3 243-266

Short RV (1972) In Hormones in Reproduction, Role of Hormones in Sex Cycles pp 42-47 Ed. CR Austin. Cambridge University Press, Cambridge

Spicer LJ, Enwright WJ, Murphy MG and Roche JF (1991) Effect of dietary intake on concentrations of insulin-like growth factor-I in plasma and follicular fluid and ovarian function in heifers Domestic Animal Endocrinology 8 431-437

Spicer LJ, Crowe MA, Prendeville DJ, Goulding D and Enwright WJ (1992) Systemic but not intraovarian concentrations of insulin-like growth factor-I are affected by short-term fasting Biology of Reproduction 46 920-925

Spicer LJ, Alpizar E and Echternkamp SE (1993) Effects of insulin, insulin-like growth factor I and gonadotropins on bovine granulosa cell proliferation, progesterone production, estradiol production and (or) insulin-like growth fact I production in vitro. Journal of Animal Science 71 1232-1241

Spicer LJ, Alpizar E and Vernon RK (1994) Insulin-like growth factor I receptors in ovarian granulosa cells: effect of follicle size and hormones Molecular and Cellular Endocrinology 102 69-76

Stanko RL, Cohick WS, Shaw DW, Harvey RW, Clemmons DR, Whitacre MD and Armstrong JD (1994) Effect of somatrotrophin and/or equine chorionic gonadotropin on serum and follicular insulin-like growth factor I and insulin-like growth factor binding proteins in cattle Biology of Reproduction 50 290-300

Stevenson KR, Gilmour RS and Wathes DC (1994) Localization of insulinlike growth factor-I (IGF-I) and -II messenger RNA and type IIGF receptors in the ovine uterus during the estrous cycle and early pregnancy Endocrinology 134 1655-1664

Sunderland SJ, Crowe MA, Boland MP, Roche JF and Ireland JJ (1994) Selection, dominance and atresia of follicles during the oestrous cycle of heifers Journal of Reproduction and Fertility 101547-555

Teissier M-P, Monget P, Monniaux D and Durand P (1994) Changes in 
insulin-like growth factor-II/mannose-6-phosphate receptor during growth and atresia of ovine ovarian follicles Biology of Reproduction 50 111-119

Ullrich A, Gray A, Tam AW, Yang-Feng T, Tsubokawa M, Collins C, Henzel W, Le Bon T, Kathuria S and Chen E (1986) Insulin-like growth factor I receptor primary structure: comparison with insulin receptor suggests structural determinants that define functional specificity EMBO Journal 5 2503-2512

Vandehaar MJ, Sharma BK and Fogwell RL (1995) Effect of dietary energy restriction on the expression of insulin-like growth factor-I in liver and corpus luteum of heifers Journal of Dairy Science 78 832-841

Wandji SA, Pelletier G and Sirard MA (1992) Ontogeny and cellular localization of ${ }^{125} \mathrm{I}$-labelled insulin-like growth factor-I, ${ }^{125} \mathrm{I}$-labelled follicle- stimulating hormone and ${ }^{125}$ I-labelled human chorionic gonadotropin binding sites in ovaries from bovine fetuses and neonatal calves Biology of Reproduction 47 814-822

Wathes DC, Perks CM, Davis AJ and Denning-Kendall PA (1995) Regulation of insulin-like growth factor I and progesterone synthesis by insulin and growth hormone in the ovine ovary Biology of Reproduction 53 882-889

Zhou J and Bondy C (1993) Anatomy of the human ovarian insulin-like growth factor system Biology of Reproduction 48 467-482

Zhou J, Chin E and Bondy C (1991) Cellular pattern of insulin-like growth factor I (IGF-I) and IGF-I receptor gene expression in the developing and mature ovarian follicle Endocrinology 129 3281-3288 